\title{
NOTARY'S RESPONSIBILITY ON AGAINST THE LAW IN THE MAKING OF AUTHENTIC AGREEMENT
}

Mohammed Kirenci

Ankara University, Turkey

kirenci95@gmail.com

\begin{abstract}
Notary is a public official authorized to make an authentic agreement and the other has the same authority as referred to in the office of the Notary Act. In Article 16 of Notary Act mentioned that one of the tasks Notary is honest and trustworthy in the running position. However, in practice many notaries who called the court to account for the authentic agreement made because it contains elements against the law. Notary actions are not in accordance with the legislation and Notary Code and has caused losses to many parties.
\end{abstract}

Keywords: Authentic Agreement; Against The Law; Responsibility.

\section{A. INTRODUCTION}

Notary known since the second century as a group of people recorded speech. Notary's Century 11-12, Notary Latijnse known that people who are appointed by the public authorities, with the purpose of serving the public interest, and should receive honorarium for their services by the general public. In the 17th century in France enacted legislation in the field of notary, then the 18th century replaced by a notary Ventosewet who introduced institutionalization aimed at providing a better guarantee for the benefit of the general public. In the 18th century, the Dutch colonial government had done colonialism in Indonesia, by adapting Ventosewet from France to be named Notariswet. Accordance with the principles of a Concordance, the law also applies in the Dutch East Indies / Indonesia on January 26, 1860 , the issuance of Notary regulations Reglement hereinafter known as Regulations Notary. ${ }^{1}$

Notary pursuant to Article 1 (1) Act No. 2 of 2014 concerning Notary is a public official authorized to make an authentic agreement and other authorities. Notary not be placed

1 https://id.wikipedia.org/wiki/Notaris, Accessed on 17 November 2017 in the judiciary, the executive and legislative branches. $^{2}$ Therefore Notary in their profession to provide public services should behave according to the rules.

Notary authority under Article 15 Act No. 2 of 2014 regarding the amendment of Act No. 30 of 2004 concerning Notary, stating that:

(1) Notary authorized to make the agreement authentic of all agreements, agreements, and determination required by legislation and / or desired by the stakeholders to be stated in the Agreement authentic, guaranteeing the creation date of the Agreement, save agreement, giving grosse, copy and quote Agreement all of it along the Agreement of making it not also be assigned or excluded to other officials or any other person specified by law.

(2) In addition to the authority referred to in paragraph (1), notary authorities also:

a. certify the signatures and set a firm date in the letter under the hand by enrolling in special books;

2 Pramoedya, 2010, Kelik and Ananto Widiatmoko, Code of Professional Ethics Legal Executives, Yusticia, Yogyakarta, p. 69. 
b. posted a letter under the hand by enrolling in special books;

c. make a copy of the original letter under the hand in the form of a copy that contains a description as written and illustrated in the letter in question;

d. approve their compatibility with a photocopy of the original letter;

e. provide legal counseling in connection with the manufacture of the Agreement;

f. make Agreement relating to land; or

g. make treatise agreement auction.

(3) In addition to the authority referred to in paragraph (1) and (2), a notary has other powers stipulated in the legislation. "

Agreement of authenticity provided for in Article 165 HIR, which sounds the same as Article $285 \mathrm{Rbg}$ is a agreement made by or before officials authorized for it, is a testament to complete between the parties to the heirs of those who got the rights from him about the contained in it, and even as a mere notification, but the latter is only notified that relate directly to the subject on the certificate.

Agreement authentic to people who can be used as evidence in writing, shall be eligible - requisites to achieve the authentic nature of the agreement made by Notary. Authentic Agreement itself has three strength of evidence that the strength of evidence that proves the formal between the parties that they had to explain what is written in the agreement. The strength of the material evidence proving that between the right parties - the true events that have occurred in the agreement. The strength of evidence that proves that the binding between the parties and third parties that on the date of the agreement in question has been facing the general staff and explain what it is written. ${ }^{3}$

Notary duties of office and authority is not solely for personal interests, but also for the benefit of society, as well as an obligation to ensure the correctness of the agreement he had done, because it is a notary demanded more sensitive, honest, fair and transparent in the manufacture of a agreement in order to ensure that all parties directly involved in the manufacture of an authentic agreement. In carrying out his duties of a Notary must cling to the Notary office code of ethics, because without it, the dignity of professionalism will be lost and no longer has the confidence of the public.

But in practice, it is often the case Notary summoned to court to testify against the agreement or letter that experience dispute. It can be said that the authentic act that created the Notary problematic, Notary has not acted in accordance with the Laws Invitation and Notary Code or be a mistake either intentionally or accidentally by one of the parties to attempt to commit fraud, causing loss to the other party.

In the Notary Act stipulated that when Notaries in performing his respective duties have offenses that cause deviations from the law, Notary may impose sanctions in the form of civil penalties, administrative or Notary Code. From pejelasan writer is interested to discuss about "accountability notaries who acted against the law in making authentic agreement"

\section{B. RESEARCH METHOD}

The research method is a scientific activity that is based on a method, systematics, and certain thoughts which aims to study a particular symptom by way of

3 Sutantio, Retnowulan and Iskandar

Oerpkartawinata, 1979, the Civil Procedure Code In Theory and Practice, CV. Mandar Maju, Bandung, p. 67. 
analyzing it, because research in the social sciences is a process that is done in a planned and systematic way to get troubleshooting and provides conclution unambiguous. ${ }^{4}$ Research is a fundamental tool in developing science and technology that aims to uncover the truth systematic, methodological and consistent, because it is through the research process conducted analysis and construction of the data has been collected. ${ }^{5}$

\section{Method Approach}

The method used in this thesis is empirical juridical approach or juridical sociology. Sociological juridical research is leaning research is qualitative, based on primary data. Primary data is data obtained directly from the object. ${ }^{6}$

Intended uses of the sociological juridical approach in this study is due to problems studied closely related to juridical factors. That is, the object of the problem under study relates to issues regulated normatively in the legislation while it uses a sociological approach, because the problems examined also there is a link between the law by factors non-judicial, that is to know the problems that arise in the Accountability Notary Yang doing Torts In Making Authentic Agreement.

\section{Specifications Research}

Specifications of this research using descriptive and qualitative nature. Descriptive research means that this study describes the nature of an individual, the state or the symptoms of a particular group and to determine the frequency or

4 Ronny Hanitijo Soemitro, 1988, Legal Research Methodology, Ghalia Indonesia, Jakarta, p.13

5 Suparmoko, 1991, Practical Research Methods, Yogyakarta, p. 1.

6 J.Supranto, 2003, "Legal Research Methods and Statistics", PT.Rineka Cipta, Jakarta, p. 2. the spread of a symptom and other symptoms in the community, ${ }^{7}$ or research to solve the problems that exist at the present time to gather data, collate, classify, analyze, and interpret, ${ }^{8}$ Performing the Notary Liability Torts In Making Authentic Agreement.

Through a descriptive study, will describe the objects or the research data is complete in all aspects fully investigated thoroughly so that the problems became apparent state and condition, without drawing conclusions that are generally applicable. Once described, then will be given the interpretation of the data, facts or issues examined, so that will be found a solution to solve problems or find solutions when obstacles or barriers arise.

\section{Sampling Method}

The population is the entire object or the entire individual or all symptoms or the entire event or the entire unit to be studied. In this study as a population are all involved with the Notary Public Accountability Conducting Torts In Making Authentic Agreement.

The sample is partially or representative of the population studied. ${ }^{9}$ Sampling is a process in selecting a representative portion of the population. ${ }^{10}$ The sampling method used non-random sampling technique, which means that only objects that meet certain requirements can be taken as a sample. In this study, obtained the samples taken are as follows:

7 Kuncoroningrat, 1981, Methods Research Society, PT.Gramedia, Jakarta, p. 42.

8 Soenarjo, 1985, Research Methods I, the State University of March, Surakarta, p. 8.

9 Suharsini Arikunto, 1998, Research Procedure A Practical Approach, Rineka Cipta, Jakarta, p. 115.

10 Ronny Hanitijo Soemitro, 1988, Legal Research Methodology, Ghalia Indonesia, Jakarta, p. 42. 
a. Own land dispute

b. Notaries who do Torts

c. 1 (one) Notary Supervisory Council of the Regional People Pati.

\section{Method of Collecting Data}

The data will be used to answer the problem of thesis research was conducted using two (2) types of data:

a. Primary data is data obtained directly from the data source. This data was obtained by conducting interviews or direct interviews with respondents. The interview is a conversation with a purpose. The conversation was conducted by the two parties, ie the interviewer (interviewer) who ask questions and interviewees (interviewee) that provide answers to the question. ${ }^{11}$ The interview itself there are various, namely the free interview, interview guided and free guided.

In all three types of interviews are known to use the free guided interview techniques. In this technique, the interviewer will ask the respondent based on a list of questions prepared in advance interviewer. The list of questions that serve as a guide of questions and answers with the respondents.

b. Secondary data is data obtained from the materials used literature references complementary materials, which consist of:

1) Secondary Legal Materials include books of literature and scientific articles or expert opinion related to the title of the thesis.
5. Method of Processing and Presentation of Data

Data have been collected through the data collection activities have not given any meaning for research purposes. The study can not be concluded for the purpose of research because the data was still a raw material, therefore the necessary effort to cultivate it. ${ }^{12}$ Data processing includes the following activities: ${ }^{13}$

1. Editing (To edit it means fixing) is Checking or research data have been obtained to ensure whether it can be justified in accordance with reality. In this editing phasecorrection correction is also carried out erroneous data, add the missing data, complete the data is not yet complete.

2. Coding that categorize the data by way of codes or symbols with the criteria required in the questions and in the questions themselves with a view to tabulate.

3. Tabulating /Tabulation is Moving data from questionnaires into tables that have been prepared for the purpose.

Once the data is processed it is believed to be complete, true and accurate, we then presented in the form of descriptions sentence systematically arranged and easy to understand to describe Responsibility Notaries Performing Torts In Making Authentic Agreement.
11 Moleong, 2005, "Qualitative Research Methodology", PT Youth Rodakaya, Bandung, p. 186.
12 Ronny Hanitijo Soemitro, "Legal Research Methodology And Jurimetri", Op. Cit, p. 64-65.

13 Ibid, p.64-65. 


\section{Methods of Analysis Research}

Data analysis methods used to solve problems is using qualitative analysis method that analyzes by describing the data field findings from interviews and documentary studies. From the data that has been analyzed to give a systematic description of the facts, properties and phenomena arising in relation to the Act that apply to the data obtained in the field. The acquired data will be assessed and linked to the prevailing laws in Indonesia so it can be concluded from this study material in order to produce answers to the problem are formulated.

\section{DISCUSSION}

Profession of a Notary shall be guided by and subject to the Act No. 2 of 2014 concerning Notary hereinafter referred UUJN. The cornerstone of the establishment filosfi UUJN and UUJN Act amendment is to guarantee the realization of the rule of law, order and legal protection that core truth and justice. Through the agreement he had done, the Notary must provide certainty and legal protection to the people who use the services of a Notary.

The importance of the role of the Notary in helping create legal certainty and legal protection for the community preventive namely preventive measure by issuing certificates authentically made dihadapanya related to the legal status, rights and obligations of a person in the law that serves as evidence of the most perfect in court in case disputes over rights and corresponding obligations. ${ }^{14}$

The relationship between the theory of liability is the problem that the authors describe is in addition to the Notary run kewenanganna as a public official has a agreement authentically good and right and

${ }^{14}$ Sjaifurrachman and Habib Adjie, 2011, the accountability aspect Notary Deed In Making, Mandar Maju, Bandung, , page 7 conformity with the provisions of the legislation in force, but did not rule in carrying out duties of a Notary Public to make mistakes in agreement that causes legal consequences for the company if the Notary make mistakes that harm the parties, the Notary may be liable for these mistakes. So the accountability theory is used to analyze what can be charged to the Notary of accountability for mistakes made by the Notary at the time of performing the task and his position.

Civil liability of a Notary Public who against the law, in this case concerns the authentic agreement. Tort committed by a Notary can be divided into 2 backwardly passive and active. Are active namely Notaries perform acts that cause harm to others. While in the passive sense Notaries do not do anything that is necessary, so that the other party suffers losses. So the elements of the tort is an error related to the unlawful and the losses incurred another person.

Notary committed an unlawful act can be based on Article 1365 of the Civil Code which states every tort that bring harm to others require a person who kearena harm in issuing losses, indemnify it. So the article was used directly as a basis to declare the Notary act is a tort.

As a result of an unlawful act committed in agreement authentic Notary raised their responsibility to be borne by the Notary for his actions. A civil judge will be involved Notary to seek the truth in the agreement formal, formal truth is the truth expressed by the parties. Notary role here is only recorded or pour a legal act performed by the parties to the authentic agreement. Notary responsible for finding the material truth of the agreement. Notaries have a neutral role in the agreement, but if the client asks notary is obliged to provide legal advice on legal act performed by the client. 
Penalties can be given to the Notary on tort is a civil sanctions. This sanction is a reimbursement, compensation, or interest should be based on a legal relationship between the parties yahng Notary to Notary, and if there are parties who directly suffered the loss of a agreement, it could also be a civil claim against the Notary.

Article 41 UUJN determine their civil sanctions. If the Notaries committed an unlawful act or a violation of article 38, 39, 40 UUJN the notarial agreement will only have the force of proof under the hand that is a proof that can not be liable for compensation dalma any form. Similarly, the cancellation of the agreement for the sake of the law, if it is deemed null and void the agreement never existed or were never made.

The conclusion of a civil liability of a Notary who melkaukan unlawful act is the
Notary shall account for his actions to the civil sanctions in the form of reimbursement or compensation to the injured party on an unlawful act committed by a Notary. But before the Notary Public Notary civil sanctions must first be proven that it has the losses suffered and tort Notary causal relationship exists, as well as the unlawful act or omission is due to an error that can be accounted to Notrais concerned.

In addition to civil liability Notaries can also be charged with administrative sanctions. Broadly speaking admininistrative sanctions can be divided into 3 kinds, reparative sanctions are aimed at the improvement of sanctions for violations of rules of law. Punitive sanctions are punitive sanctions, an additional punitive sanctions. Regressive sanctions are sanctions in reaction to something disobedience.

\section{BIBLIOGRAPHY}

J.Supranto, 2003, "Legal Research Methods and Statistics", PT.Rineka Cipta, Jakarta.

Kuncoroningrat, 1981, Methods Research Society, PT.Gramedia, Jakarta.

Moleong, 2005, "Qualitative Research Methodology", PT Youth Rodakaya, Bandung.

Pramoedya, 2010, Kelik and Ananto Widiatmoko, Code of Professional Ethics Legal Executives,

Yusticia, Yogyakarta.

Ronny Hanitijo Soemitro, 1988, Legal Research Methodology, Ghalia Indonesia, Jakarta.

Ronny Hanitijo Soemitro, 1988, Legal Research Methodology, Ghalia Indonesia, Jakarta.

Sjaifurrachman and Habib Adjie, 2011, the accountability aspect Notary Deed In Making, Mandar Maju, Bandung.

Soenarjo, 1985, Research Methods I, the State University of March, Surakarta.

Suharsini Arikunto, 1998, Research Procedure A Practical Approach, Rineka Cipta, Jakarta.

Suparmoko, 1991, Practical Research Methods, Yogyakarta.

Sutantio, Retnowulan and Iskandar Oerpkartawinata, 1979, the Civil Procedure Code In

Theory and Practice, CV. Mandar Maju, Bandung.

https://id.wikipedia.org/wiki/Notaris, Accessed on 17 November 2017 